\title{
Pathological changes caused by cold-water stress in Japanese eel Anguilla japonica
}

\author{
Tatsuya Kobayashi, Kuniko Goto, Teruo Miyazaki* \\ Faculty of Bioresources, Mie University, 1515 Kamihama, Tsu, Mie 514-8507, Japan
}

\begin{abstract}
In the present study, histopathological changes in Japanese eel Anguilla japonica subjected to 'cold-water stress' were examined. Eels were exposed to cold water $\left(13\right.$ to $\left.15^{\circ} \mathrm{C}\right)$ and warmer water $\left(25^{\circ} \mathrm{C}\right)$ as controls. Fish held in warm water did not show any apparent changes. Although none of the eels exposed to cold water died, they displayed nephrotic changes such as cloudy swelling and hyaline droplet degeneration of the renal tubular epithelia. Fish with nephroses had low levels of serum chloride $\left(12\right.$ to $23 \mathrm{mg} \mathrm{l}^{-1}$ in fish with hyaline droplet degeneration, 71 to $81 \mathrm{mg} \mathrm{l}^{-1}$ in fish with cloudy swelling) compared with the control fish (87 to $109 \mathrm{mg}^{-1}$ ). In electron microscopy, affected tubular cells had variously damaged mitochondria and formations of secondary lysosomes of variable sizes. Electron microscopy also revealed mitochondrial degeneration in hepatocytes and degenerated granules of neutrophils in the hematopoietic tissue. 'Cold-water stress' was effective in damaging Japanese eels below $15^{\circ} \mathrm{C}$.
\end{abstract}

KEY WORDS: Cold-water stress - Japanese eel - Nephroses - Mitochondrial degeneration

\section{INTRODUCTION}

In warmwater fishes such as Japanese eel Anguilla japonica, Japanese flounder Paralichthys olivaceus and goldfish Crassius auratus, viral infections usually occur in cold water although the causative viruses can multiply in vitro at warmer temperatures. For example, Rhabdovirus anguillae was successful in infecting Japanese eels (rhabdoviral dermatitis) that were held at $15^{\circ} \mathrm{C}$ but the infection failed at over $20^{\circ} \mathrm{C}$. It was possible for this virus to multiply in vitro between 10 and $25^{\circ} \mathrm{C}$, and a temperature of $15^{\circ} \mathrm{C}$ did not necessarily enhance the viral activity (Kobayashi \& Miyazaki 1996, Kobayashi et al. 1999). Similar dependence of viral diseases on low temperatures was also found for infections with Rhabdovirus olivaceus in Japanese flounder (hirame rhabdovirus disease: Kimura et al. 1986, Oseko et al. 1988), a herpesvirus causing hematopoietic necrosis of goldfish (Jung \& Miyazaki 1995), Herpesvirus cyprini (epidermal hyperplasia of

•Corresponding author. E-mail: miyazaki@bio.mie-u.ac.jp carp: Sano et al. 1993), and Rhabdovirus carpio (spring viremia of carp: Fijan et al. 1971, Fijan 1976) as well as redfin perch iridovirus (epidemic hematopoietic necrosis: Langdon \& Humphrey 1987). These warmwater fishes were readily infected with the viruses above in cold water. Cold temperatures, thus, appear not only to facilitate viral activity in warmwater fishes, but rather to cause 'cold-water stress', which may be an important factor for facilitating viral infections. Moreover, it is known that eels that experienced cold water in open-air ponds displayed severe nephroses and mortality in winter (Egusa 1970). Similarly, yellowtail Seriola quinqueradiata and red sea bream Pagrus major often displayed ascites, hemorrhage and skin ulceration when they were exposed to cold water (at about 15 to $16^{\circ} \mathrm{C}$ ) in winter (Miyazaki unpubl. data). Thus, cold water is considered to act as a severe stressor to warm water fishes.

In the present study, we subjected Japanese eel to 'cold-water stress' and investigated its effect by means at histological and electron microscopic examinations. This is the first report of cytological changes that occurred under 'cold-water stress' 


\section{MATERIALS AND METHODS}

In order to assure for significant replication we sequentially performed 3 experiments in which Japanese eels were subjected to cold water. In each experiment, 5 eels (mean body weight: $50 \mathrm{~g}$ ) were exposed to cold water (between 13 and $15^{\circ} \mathrm{C}$ ) and the same number of eels were held at $25^{\circ} \mathrm{C}$ as a control in an aquarium without feeding. For the cold-water experiments, a cooling unit was used to decrease the water temperature from room temperature to the set temperature over a $3 \mathrm{~d}$ period. The low water temperature varied slightly due to the performance of the cooling unit. Similarly, for the control fish, the water was gradually hoatcd to $25^{\circ} \mathrm{C}$ over a 3 d perind No mortality occurred in any of 3 experiments. The fish were sampled after 4 to 6 wk because some fish were weakened by the treatment. In the first experiment, histological examinations revealed the occurrence of nephroses in these weakened fish from the cold-water group. Moreover, it has been proposed that a combination of nephroses and low levels of serum chloride occurs in branchionephritis (erajin-en in Japanese), which is a wellknown cold-water disease in Japanese eels (Egusa 1978). Therefore, in the second and third experiments, blood was also taken from all eels to determine serum chloride levels. Blood was removed from the bulbus arteriosus with a $1 \mathrm{ml}$ syringe while fish were anesthetized with $1.5 \%$ urethane solution before dissection. After clotting at $4^{\circ} \mathrm{C}$, the sera were separated by centrifugation of the blood at $3000 \mathrm{rpm}$ for $5 \mathrm{~min}$. Serum chloride was examined with an automatic blood analyzer (Schales-Schares method, Hitachi 7350). After external and internal examinations of all fish, the skin, lateral muscle, gills, kidney, heart, stomach, intestine, spleen and liver were dissected and fixed in $10 \%$ phosphate buffered formalin or Bouin's fluid for histological studies. The fixed tissues were prepared according to standard techniques and stained with hematoxylin \& eosin (H\&E), Azan, Giemsa and Weigert's fibrin stain. Moreover, pieces of the remaining kidney and liver were fixed in $70 \%$ Karnovsky's solution, postfixed in $1 \% \mathrm{OsO}_{4}$ and processed for electron microscopy according to standard techniques.

\section{RESULTS}

\section{Histopathological changes and electron microscopy}

None of the eels in the control groups showed any histological changes except for slight atrophy accompanied by decreased amounts of glycogen in the hepatocytes, which is indicative of long-term suspension of feeding. None of the eels subjected to cold water showed mortality or any external changes. In histopathological examinations, the kidneys of all fish displayed nephrotic signs, but the severity varied among individuals. In a total of 9 fish from 3 experiments ( 3 fish in each experiment), the renal epithelial cells showed cloudy swelling, and eosinophilic fine granules were present in the swollen cytoplasm. These granules were more distinct in the proximal tubules than in the distal tubules (Fig. 1B). In some kidneys, there was also a small number of cells displaying hyaline droplet degeneration. The glomeruli usually did not exhibit any obvious change except for some cases which showed slight damage of the podocytes. The other 6 fish (2 fish from each experiment) displayed hyaline droplet degeneration in the epithelial cells of both the proximal and distal tubules in the kidney (Fig. 1A). The hyaline droplets were usually round, oval or irregularly round, and varied in size from smaller than nuclei to larger than nuclei. They were acidophilic and positive in PAS (periodic acid Schiff) reaction and Weigert's fibrin stains, which suggested that the droplets were made up of peptides. The affected cells were full of these droplets, and the nuclei had moved to the basal side of cells and were accompanied by cytoplasmic vacuolization. Some glomeruli displayed hyaline droplet degeneration of the mesangial cells and podocytes. Moreover, neutrophils having apparent acidophilic granules increased in number in the hematopoietic tissue, although the severity was variable among individuals. In the liver, hepatocytes containing enlarged lipid droplets increased in number around the central veins (Fig. 1C) whereas the other hepatocytes usually contained fine lipid granules or no lipid. Epithelial cells of gill lamellae were slightly swollen although hyperplastic change did not occur. The heart, stomach, intestine, spleen, skin and lateral musculature did not show any apparent histopathological signs

Electron microscopic examinations (EM) were performed in renal tubular epithelia, neutrophils in the hematopoietic tissue and hepatocytes because histological examinations revealed evidence of pathological changes such as those described previously. In the control fish, the renal tubular epithelial cells usually had membrane-bound phagosomes containing electron-dense peptide, lysosomes, Golgi's apparatus and vesicles, and glycogen granules were located in the upper portion of the cells (Fig. 2A), while large numbers of long mitochondria longitudinally oriented within well-developed, interdigitating processes were present chiefly in the basal region of the cells (Fig. 2B). These mitochondria usually contained an electrondense, granular matrix and many matrical electrondense granules that were assumed to be divalent cation localization (Ghadially 1982). In contrast, in the cold- 
treated fish, most tubular epithelial cells that showed cloudy swelling displayed variously damaged mitochondria, cytolysosome-like bodies with membranous formations which were derivatives of lysosomes and degenerated mitochondria (Ghadially 1982), phago- somes with a severly damaged membrane, and free deposits of peptides with high electron density (Fig. 2C). Mitochondrial degeneration was variable. Most mitochondria had severly damaged cristae and were rounded or fragmented; some of them were also

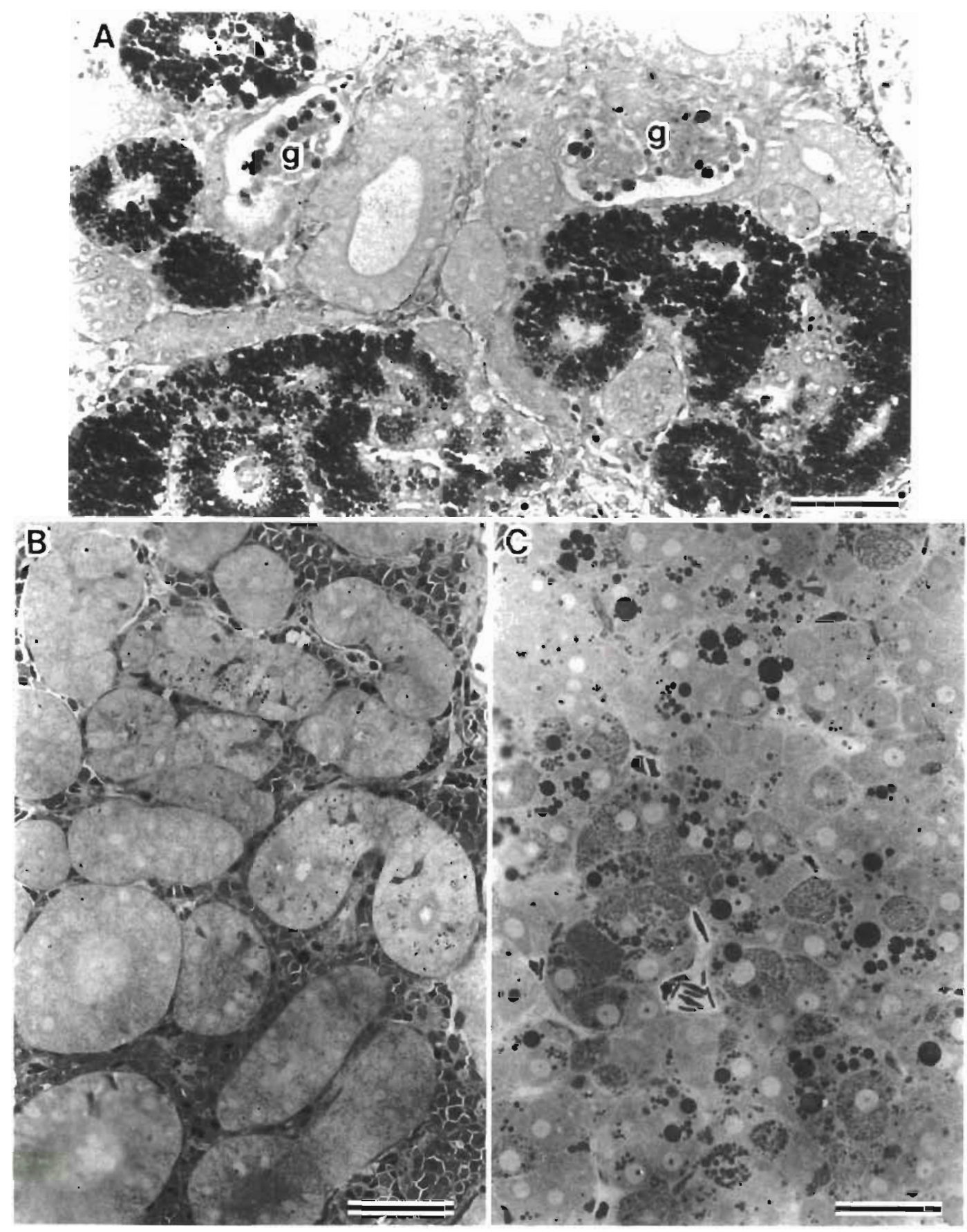

Fig. 1. Anguilla japonica. Histopathological changes in the cold-treated fish. (A) Hyaline droplet degeneration occurs in renal tubular epithelia and in glomeruli $(\mathrm{g})$. Hyaline droplets are positive in Weigert's fibrin stain. Scale bar $=50 \mu \mathrm{m}$. (B) Renal tubular epithelial cells show cloudy swelling. Semi-thin section. Toluidine blue stain. Scale bar $=50 \mu \mathrm{m}$. (C) Hapatocytes show large lipid droplets. Semi-thin section. Toluidine blue stain. Scale bar $=75 \mu \mathrm{m}$ 


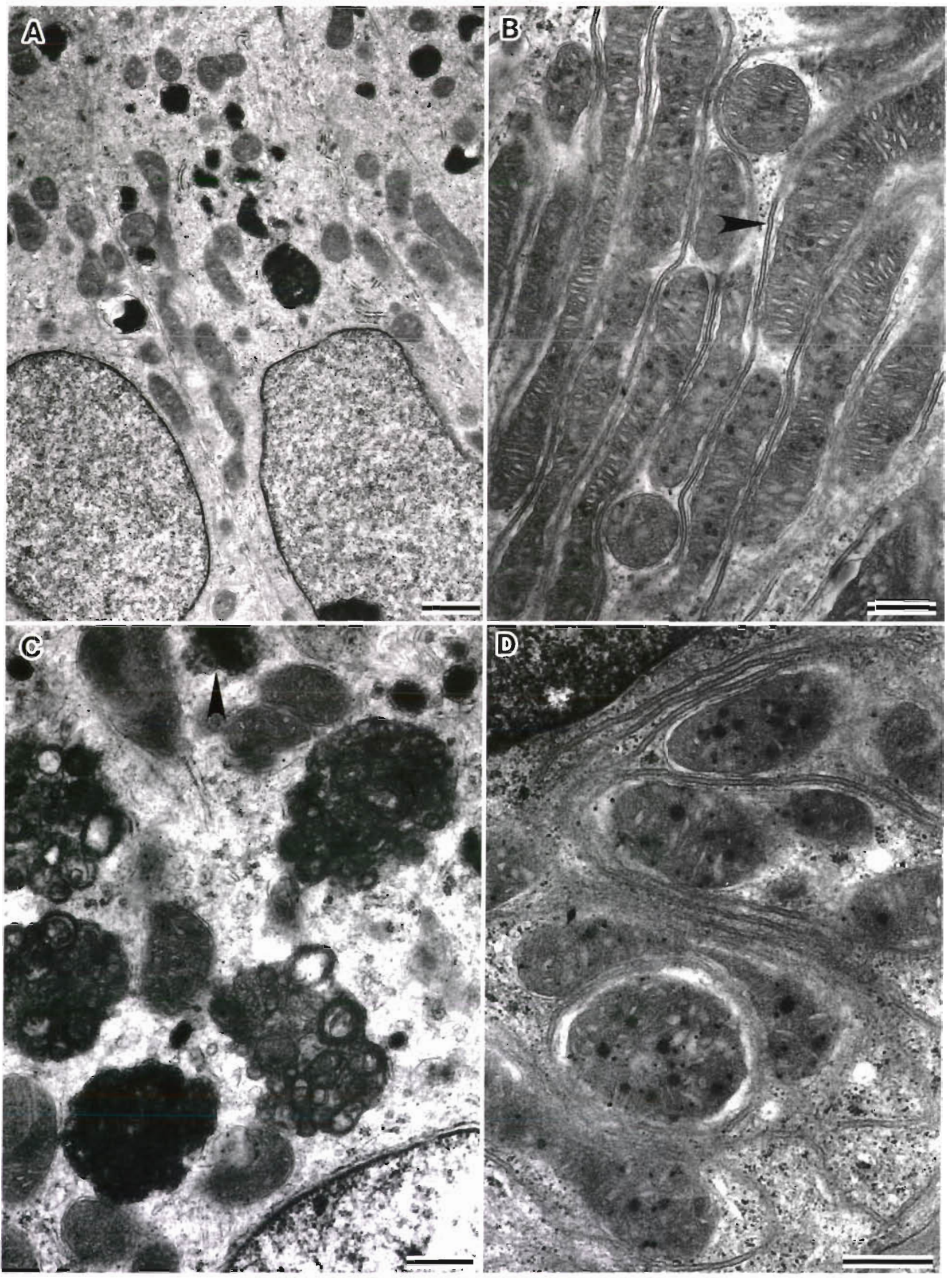


Fig. 2. Anguilla japonica. Electron micrographs of epithelial cells of renal tubules in control fish (A, B) and tubular cells that show cloudy swelling in the cold-treated fish (C, D). (A) Many mitochondria, membrane-bound phagosomes containing electron-dense peptide, lysosomes and rough endoplasmic reticula (rER) are located in the upper portion of the cell. Scale bar $=1000 \mathrm{~nm}$. (B) Large numbers of long mitochondria longitudinally oriented within the well-developed, interdigitating processes (an arrowhead shows one of them) are chiefly located in the basal region of the cell. Scale bar $=600 \mathrm{~nm}$. (C) Many degenerated mitochondria and cytolysosome-like bodies with membranous formations, and free masses of deposited peptide (arrowhead) appear in the upper portion of the cell. Scale bar $=600 \mathrm{~nm}$. (D) In the basal region of the cell, most of mitochondria are degenerated, fragmented and rounded, showing destroyed cristae within interdigitating processes. Around degenerated mitochondria, glycogen granules are abundant. Scale bar $=600 \mathrm{~nm}$

swollen (Fig. 2D). In addition, there were mitochondria in which the cristae had been completely destroyed and the inside replaced with less electron-dense materials. Glycogen granules were present and dominated in the area around these degenerated mitochondria. Moreover, some cells showed formations of many small particles of secondary lysosomes (Junqueira \& Carneiro 1980) in addition to damaged mitochondria, and the nucleus had moved to the basal region of the cells. These affected epithelial cells occurred in both the proximal and distal tubules.

Tubular cells showing hyaline droplet degeneration contained large numbers of electron-dense bodies of secondary lysosomes (Fig. 3A). The secondary lysosomes had round, oval and polygonal shapes, and their sizes varied from smaller than the nucleus to larger than the nucleus because of the fusion of 2 or more of them. These secondary lysosomes had granular contents or were totally electron-dense bodies, some of which contained highly electron-dense spots. Their bounding membranes were unclear. Among these secondary lysosomes, a small number of mitochondria remained but were markedly deformed and compressed. Their cristae were distinct, but the matrix was clear because of a markedly decreased number of matrical granules. Moreover, interdigitating processes were less affected but were close to each other between secondary lysosomes. These affected cells appeared in both the proximal and distal tubules.

In the hematopoietic tissue of the control fish, stem cells, hematopoietic blast cells and neutrophils looked normal. Neutrophils usually had spindle-shaped granules with a distinct outline (Fig. 3B). As described in cold-water fish, neutrophils with apparent acidophilic granules appeared in the hematopoietic tissue. In EM, they showed swollen granules with less sharp outlines and increased numbers of vesicles (Fig. 3C). Moreover, in the control fish, the hepatocytes usually had mitochondria with an electron-dense matrix, rough endoplasmic reticula (rER) with a normal appearance, less abundant glycogen granules, a few lysosomes and fine lipid droplets (Fig. 4A,B). In contrast, in cold-water fish, the hepatocytes usually had many degenerated mitochondria which were rounded and had severely damaged cristae in the electron-lucent cytoplasm (Fig. 4C). Most of rER were fragmented and rounded. Lysosomes had increased in number although there was no formation of secondary lysosomes with damaged mitochondria. Glycogen granules usually were abundant while there were cells with almost no glycogen. Large lipid droplets had formed in many cells (Fig. 4D).

\section{Serum chloride}

Because the treated eels were small in a size, only small amounts of serum $(0.2$ to $0.3 \mathrm{ml})$ were obtained from each individual. To obtain enough serum (about $0.5 \mathrm{ml}$ ) for serum chloride determination, some pairs of serum samples had to be combined. In the control groups, the mean level of serum chloride $(5$ samples of 10 fish) was $99 \mathrm{mg} \mathrm{l}^{-1}$ ( 87 to $109 \mathrm{mg} \mathrm{l}^{-1}$ ). In contrast, the mean level of serum chloride in fish that showed cloudy swelling of renal epithelia (4 samples from 6 fish) was $75 \mathrm{mg} \mathrm{l}^{-1}$ ( 71 to $81 \mathrm{mg} \mathrm{l}^{-1}$ ). The mean level of serum chloride in fish that showed hyaline droplet degeneration in renal epithelia ( 3 samples from 4 fish) was $18 \mathrm{mg} \mathrm{l}^{-1}\left(12\right.$ to $\left.23 \mathrm{mg} \mathrm{l}^{-1}\right)$.

\section{DISCUSSION}

In the present study, eels were exposed to cold water for 4 to $6 \mathrm{wk}$ and displayed severe cellular damage. The cellular damage was due to mitochondrial degeneration and suggested reduced activities of cells. Because of the length of the cold-water exposure, this cellular damage was considered to be a reaction to the state of exhaustion (or maladaptation) of the fish experienced under 'cold-water stress'. In previous studies of viral diseases, eels and Japanese flounder were usually found to suffer from rhabdoviral dermatitis (Kobayashi \& Miyazaki 1996) and hirame rhabdovirus disease (Isshiki et al. unpubl. data) respectively when they experienced cold water in both natural outbreaks and infectivity experiments. These diseased fishes mostly showed hyaline droplet degeneration in the 


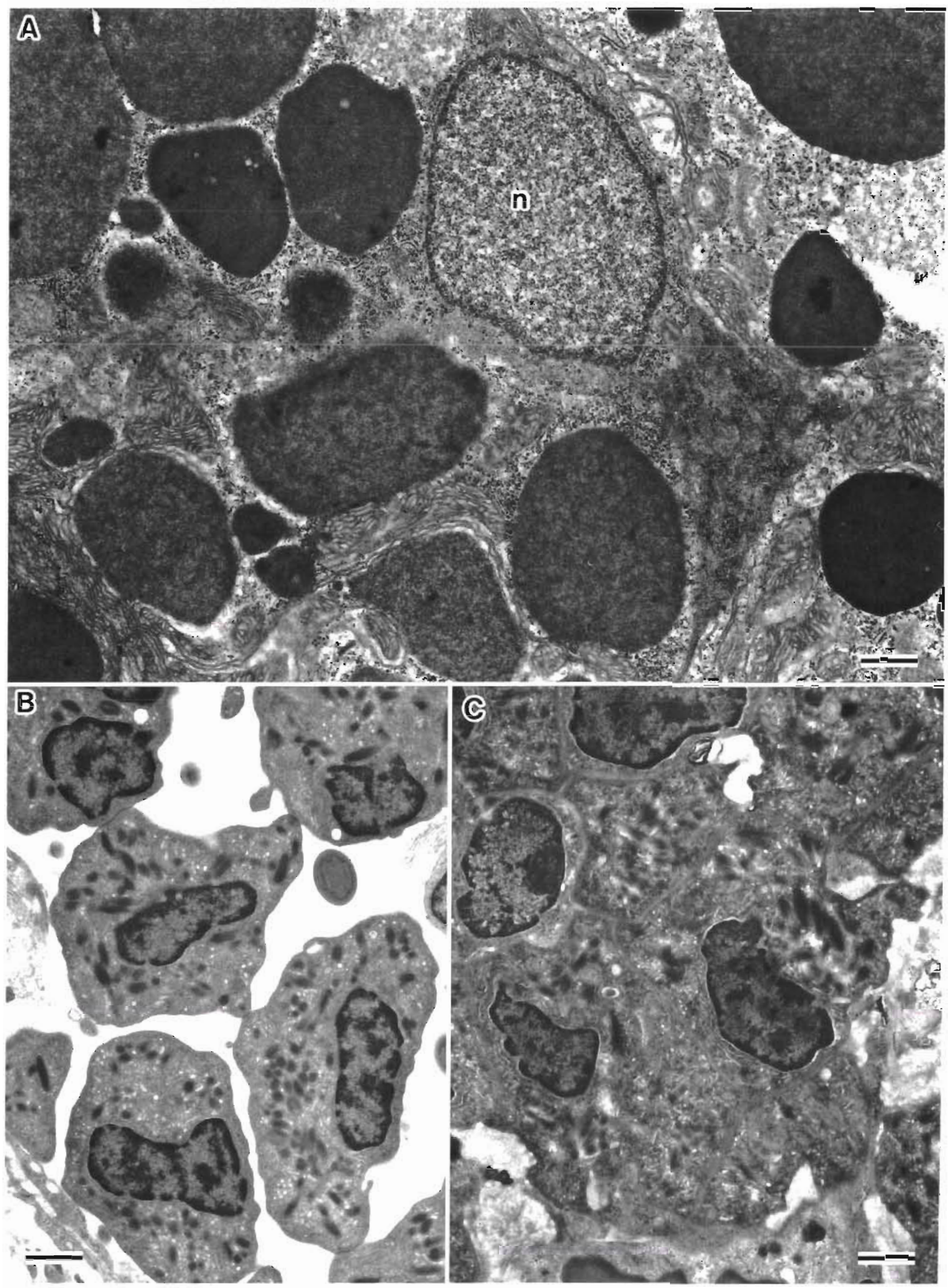


Fig. 3. Anguilla japonica. (A) In a cell displaying hyaline droplet degeneration, many large secondary lysosomes are formed among deformed mitochondria and interdigitating processes. n: nucleus. Scale bar $=1000 \mathrm{~nm}$. (B) Neutrophils in the hematopoietic tissue of a control fish have spindle-shaped granules a with distinct outline. Scale bar $=140 \mathrm{~nm}$. (C) Neutrophils in the hematopoietic tissue of the cold-treated fish have swollen granules with less distinct outlines and abundant vesicles. Scale bar $=140 \mathrm{~nm}$

renal tubular epithelia. This nephrotic change was revealed to be independent of virus infection because there was no evidence of virus particles in the affected cells in either diseased eels or diseased flounders in EM. Sano (1976) also reported the occurrence of severe nephroses as hyaline droplet degeneration in Japanese eels artificially infected with a birnavirus at low temperatures $\left(8\right.$ to $14^{\circ} \mathrm{C}$ ), while the association of the birnavirus with nephroses has not been confirmed. A comparison of hyaline droplet degeneration in renal tubular cells, showed that the features were mostly the same between the above viral infections and 'coldwater stress' described here. Moreover, some previous studies have reported that the low temperatures impair activities relating to the defence mechanisms of warmwater fishes (Rijkers et al. 1980, Oseko et al. 1988, Roberts 1989, Hung et al. 1993, Matsuyama et al. 1998). Although these studies did not investigate any cytological changes, cellular elements such as neutrophils, macrophage and lymphocytes in the defence system appeared to be affected under 'cold-water stress' in the same manner as those in the present study. Thus, the state of maladaptation/exhaustion of fishes suffering from 'cold-water stress' appears to facilitate these viral infections.

In the state of exhaustion due to 'cold-water stress', cellular damage was most apparent in the renal tubular epithelial cells and cloudy swelling and hyaline droplet degeneration were evident. The fine granules observed in cells showing cloudy swelling under the light microscope appeared to be degenerated mitochondria, small secondary lysosomes, cytolysosomelike bodies and masses of deposited peptides in EM. In cells displaying hyaline droplet degeneration, EM revealed formations of many large secondary lysosomes. In these cells, mitochondria had markedly decreased in number and damaged mitochondria had almost disappeared in contrast to those in cells with cloudy swelling. Secondary lysosomes are formed by fusion of primary lysosomes with damaged mitochondria as well as phagosomes containing reabsorbed peptides (Ross et al. 1989). The decrease in damaged mitochondria appears to be due to their removal by fusion with primary lysosomes. Hyaline droplets appear to have been enlarged by the subsequent fusion of secondary lysosomes. Interdigitating processes would be close to each other, apparently because of the removal of damaged mitochondria.
Renal tubular epithelial cells act to reabsorb peptides, glucose, ions and water from the urine (Ross et al. 1989). Reabsorbed glucose and ions are recognized to be actively transported through the cytoplasm into capillaries along with the renal tubule. The reabsorbed peptides within phagosomes are usually digested by fusion with primary lysosomes. Transportation and digestion of reabsorbed materials depend on energy (ATP: adenosine triphosphate) which is generated by mitochondria. Indeed, the normal mitochondria of tubular epithelial cells have a highly electron-dense matrix and this indicates that they must generate high levels of ATP to ensure cell performance. However, in the fish that experienced 'cold-water stress', mitochondria had markedly degenerated, which suggested disturbance of ATP generating activities. Therefore, this would have caused the contents of secondary lysosomes to be left undigested, which could account for the fine granules and hyaline droplets. Moreover, these affected cells had an increased number of glycogen granules. The accumulation of glycogen granules would indicate a disturbance in the transportation of reabsorbed glucose and nonconsumption by degenerated mitochondria. These cells also would be unable to reabsorb ions from the urine or to transport them. The decreased amounts of serum chloride observed in the cold-treated eels could have been caused by a disturbance in reabsorption and transportation of $\mathrm{NaCl}$ by renal epithelial cells because no change occurred in the chloride cells in the gills. Thus, these nephrotic changes are recognized to be caused by the degeneration of mitochondria.

Similar damage to mitochondria was found in the hepatocytes. In spite of long-term suspension of feeding, large lipid droplets formed in these hepatocytes. Based on the results of the present study, cold-water exposure directly damages mitochondria in various cells, which impairs cellular activities. Moreover, the resulting reduction of serum $\mathrm{NaCl}$ may damage systemic cellular osmoregulation. Indeed, affected hepatocytes usually had electron-lucent cytoplasm, which appears to be indicative of a watery cytoplasm. Neutrophils displayed damaged granules and abundant vesicles instead of damaged mitochondria, which suggests that the ability of the affected neutrophils to defend themselves against invading pathogens is impaired. These changes which occur in the state of exhaustion are expected to systemically reduce cellu- 

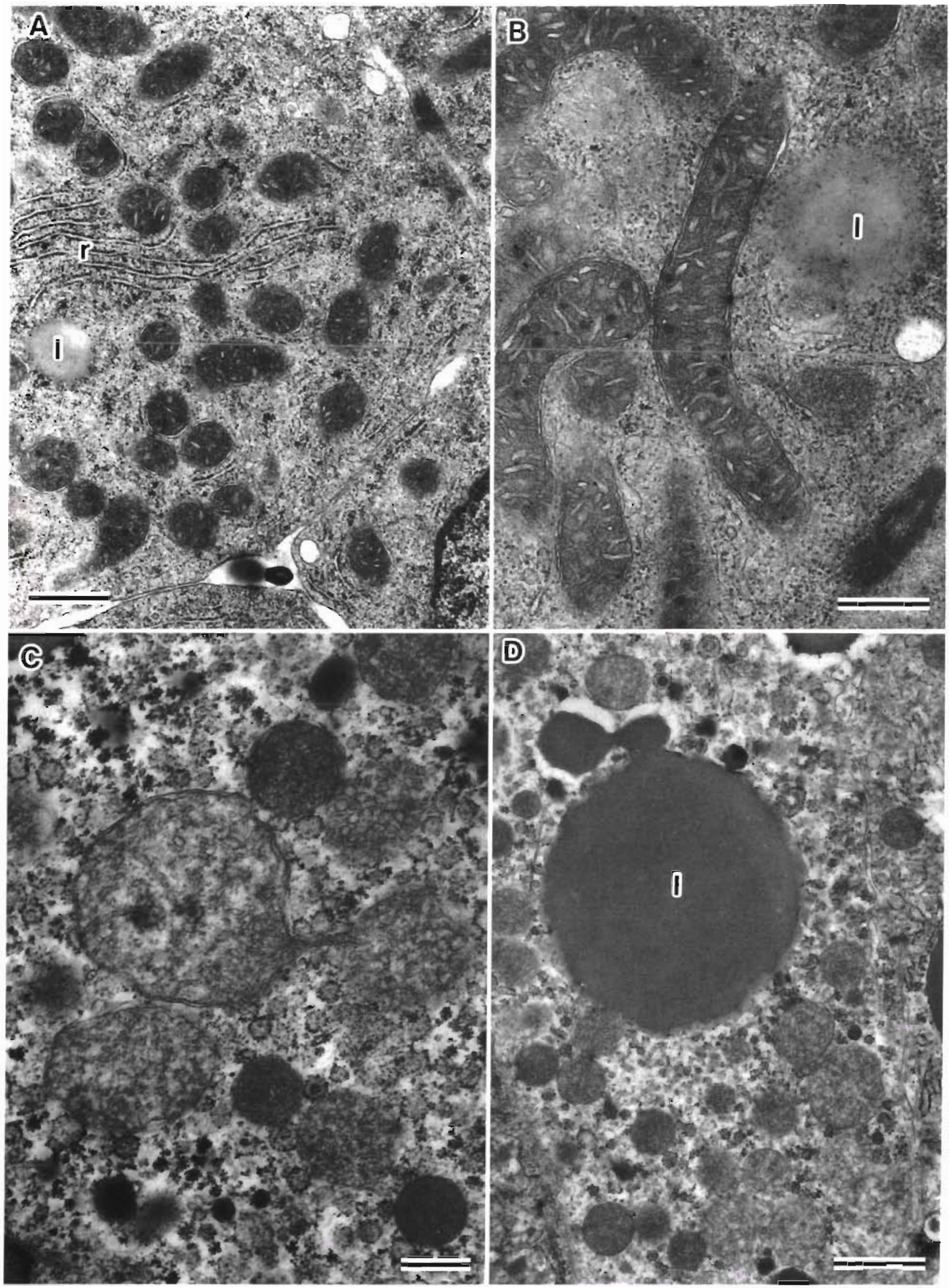
Fig. 4. Anguilla japonica. Electron micrographs of hepatocytes in the control fish (A, B) and in the cold-treated fish (C, D). (A) Hepatocytes have normal-looking mitochondria and $\mathrm{rER}$ ( $\mathrm{r}$ ), and less distinct lipid droplet (l). Scale bar $=1000 \mathrm{~nm}$. (B) A highpower view of mitochondria which look normal. Lipid droplet (l) is less distinct. Scale bar $=600 \mathrm{~nm}$. (C) Most of mitochondria are degenerated and show severely damaged cristae. Many rER are fragmented and rounded. Lysosomes have increased in number. Glycogen granules are abundant in the electron-lucent cytoplasm. Scale bar $=600 \mathrm{~nm}$. (D) Large lipid droplets (1) have formed among degenerated mitochondria and fragmented rER. Scale bar $=1000 \mathrm{~nm}$

lar activities, including the defence mechanisms of eels. Surprisingly, such 'cold-water stress' was effective at around $15^{\circ} \mathrm{C}$, so eels need to hibernate in order to protect themselves in cold water.

A similar combination of nephroses, low levels of serum chloride and cold water were noticed in branchionephritis of Japanese eels. In the winter season between 1969 and the mid-1970s, this disease was accompanied by mass mortality in open-air ponds. The diseased eels stayed in cold water on the muddy bottoms of the ponds, whereas healthy fish were located within the mud, where they were hibernating. The diseased fish usually had decreased levels of serum chloride, gill lesions and severe nephroses (Egusa 1970, 1978, Egusa et al. 1971). Although Egusa (1978) speculated that gill lesions and nephroses would have a different etiology, their etiologies have not yet been revealed. While bacterial gill disease was doubted as the main etiological agent of the gill lesions, a cytophaga-like bacterium was frequently isolated from lamellar lesions. In addition, treating the fish with branchionephritis with a combination of heated water (increased to $29-30^{\circ} \mathrm{C}$ from $13-15^{\circ} \mathrm{C}$ ) and oral administration of oxytetracycline was effective in removing cytophaga-like bacteria from gills and reducing mortality (Miyazaki et al. 1974). These facts indicate that gill lesions are caused by the bacterial infection. On the other hand, the kidney with nephroses markedly showed destruction of glomeruli, and cloudy swelling and hyaline droplet degeneration of the tubular epithelial cells. As mentioned above, branchionephritis occurred in cold water and diseased eels usually showed the same nephrotic changes and reduced serum chloride that were observed in the cold-treated eels in this study. Moreover, it was noticed that eels never show the symptoms of branchionephritis in warmwater ponds while branchionephritis was prevalent in cold-water ponds (Miyazaki unpubl. data). Diseased fish have not appeared since the late 1970s, because most eel farmers learned of the efficacy of warmwater rearing in preventing outbreaks of branchionephritis and now rear eels in warmwater ponds with an oil-boiler system inside greenhouses. This system has been employed by eel farmers that are located even in the southern regions in Japan. In these indoor ponds, the water temperature is maintained between 20 and $30^{\circ} \mathrm{C}$ throughout the year. As a result, bran- chionephritis has not attracted the attention of fish pathologists. The above facts and the results of the present study suggest that the nephroses and low serum chloride of branchionephritis were caused by 'coldwater stress'. Thus, a combination of gill lesions due to a cytophaga-like bacterium and nephroses due to 'cold-water stress' appears to cause branchionephritis and mass mortalities in eels in the winter season.

\section{LITERATURE CITED}

Egusa S (1970) Branchionephritis prevailed among eel populations in farm-ponds in winter of 1969-70. Fish Pathol 5:51-66 (in Japanese)

Egusa S (1978) Infectious diseases of fishes. Kouseisha-kouseikaku, Tokyo (in Japanese)

Egusa S, Hirose H, Wakabayashi H (1971) A report of investigations of branchionephritis of cultured eel. II. Condition of gills and serum ion concentrations. Fish Pathol 6:57-61 (in Japanese)

Fijan N (1976) Diseases of cyprinids in Europe. Fish Pathol 10:129-134

Fijan N, Petrinec Z, Sulimanovic D, Zwillenberg LO (1971) Isolation of viral causative agent from the acute form of infectious dropsy of carp. Vet Arch 41:125-138

Ghadially FN (1982) Ultrastructural pathology of the cell and matrix, 2nd edn. Butterworths, London

Hung $H_{\text {, Lo }}$, Tseng C, Kou G (1997) Antibody production in Japanese eel. Anguilla japonica Temminck \& Schlegel. J Fish Dis 20:195-200

Jung S, Miyazaki T (1995) Herpesviral haematopoietic necrosis of goldfish, Carassius auratus (L.). J Fish Dis 18: 211-220

Junqueira LC, Carneiro J (1980) Basic histology, 3rd edn. Lange Medical Publications, Los Altos

Kimura T, Yoshimizu M, Gorie S (1986) A new rhabdovirus isolated in Japan from cultured hirame (Japanese flounder) Paralichthys olivaceus and ayu Plecoglossus altivelis. Dis Aquat Org 1:209-217

Kobayashi T, Miyazaki T (1996) Rhabdoviral dermatitis in Japanese eel, Anguilla japonica. Fish Pathol 31:183-190 (in Japanese)

Kobayashi T, Shiino T, Miyazaki T (1999) The effect of water temperature on rhabdoviral dermatitis in the Japanese eel, Anguilla japonica Temminck \& Schlegel. Aquaculture 170:7-15

Langdon JS, Humphrey JD (1987) Epizootic haematopoietic necrosis, a new viral disease in redfin perch, Perca fluviatilis L., in Australia. J Fish Dis 10:289-297

Matsuyama T, lida T, Endo M (1998) Leukocyte collection in the swim-bladder. Kaiyo Monthly (Spec edn) 14 140-144 (in Japanese)

Miyazaki T, Kubota SS, Asano T, Tomita Y (1974) Therapies of Erajin-en (gill and kidney inflammation) occurred pondreared Japanese eels. Fish Pathol 9:84-90 (in Japanese) 
Oseko N, Yoshimizu M, Kimura T (1988) Effect of water temperature on artificial infection of Rhabdovirus olivaceus (hirame rhabdovirus: HRV) to hirame (Japanese flounder, Paralichthys olivaceus). Fish Pathol 23:125-132 (in Japanese)

Rijkers GT, Frederix-Walters EMH, Van Muiswinkel WB (1980) The immune system of cyprinid fish. Kinetics and temperature dependence of antibody-producing cell in carp (Cyprinus carpio). Immunology 41:91-97

Editorial responsibility: Carl Schreck,

Corvallis, Oregon, USA
Roberts RJ (1989) Fish pathology, 2nd edn. Bailliere Tindall, London

Ross MH, Reith ED, Romrell LJ (1989) Histology, 2nd edn Williams \& Wilkins, Baltimore

Sano T (1976) Viral diseases of cultured fishes in Japan. Fish Pathol 20:381-388

Sano N, Moriwake M, Sano T (1993) Herpesvirus cyprini: thermal effect on pathogenicity and oncogenicity. Fish Pathol 28:171-175

Submitted: July 20, 1999; Accepted: November 29, 1999 Proofs received from author(s): January 31, 2000 